\title{
軽費老人ホーム入所に至る要因と入所後の生活 高秢者の生活拠点移動に関する研究 I \\ CAUSES TO MOVE INTO AND SOCIAL ACTIVITIES \\ IN THE HOUSING FOR THE ELDERLY \\ A study on residential change in aging Part I
}

\author{
大原一興*, 鈴木成文** \\ Kazuoki OHARA and Shigebumi SUZUKI
}

\begin{abstract}
The problem of residential life and social interaction in the housing for the elderly as related to residental change was reported in this study. 95 residents' activity status in two housings were obtained by interviews. The study showed that two groups were revealed by the causes to relocation, the one group had experiented evident life events and the other had no. In addition, the social interaction and activity were suggested to have been decreased by relocation.
\end{abstract}

The contents of this paper are as follows;

1. Introduction

2. Outline of the investigations

3. Pre-relocation study : study on the causes to move into the housing for the elderly

4. Post-relocation study : study on social activities of residents

5. Correlation between typical groups

6. Conclusion

Keywords: housing for the eldery, residential home, residential change, causes to move into the housing, social activities, relocation effect

高齢者集合住宅，老人ホーム，生活拠点移動，入居要因，社会的生活，移動の影響

\section{1.はじめに}

高齢者の急激に進むわが国では, 老人居住施設の整備 は重要な課題とされている。現行制度による施設体系に おいては，居住施設がケアサービスの機能別に類型化さ れ供給されている。この場合, サービスを享受する側は 本人の心身機能の低下などによる要求変化に伴い, 住宅, 老人ホーム, 病院など生活拠点の移動を余儀なくされる。 このことから生活拠点の移動が本人の生活にとって持つ 意味を考察することは, 老人居住施設の計画上, 重要な 課題である。

これまでにも，移動による心身への影響を採り上げた 研究は数多く海外でおこなわれている1)。しかし, 施設 生活は本人個人の生活歴において前住居における生活亡 密接にかかわるため, 影響は一概には定式化しにくい。
むしろ入所前の様々な生活条件を捉えることが，施設入 所生活を理解する上で有効と思われる。さらに入所せざ るを得ない状況をとらえることによって，在宅生活を持 続するための条件について，また施設の役割について考 察することも可能である。このように，高秢者の生活に おける生活拠点移動のもつ意味をとらえるためには，入 所に至るプロセスを含め, 入所前後の生活を一連のもの として把握することが必要である。

そこで, 本報告では自宅と居住施設の関係から老人の ケアサービス体系の見直しを図るため,生活执点移動(自 宅と入所施設などの間の移動）の要因と, 移動したこと により生じると考えられる様々な生活特性をとらえ, 生 活拠点移動が高齢者の居住生活に与える意味について考 察することを目的としている。

\footnotetext{
本論文は, 昭和 60 年度日本建築学会大会にて発表した内容に加筆, 訂正を加えたものである。

*横浜国立大学工学部建設学科建築学教室 助手. Research Assoc., Dept. of Architecture, Faculty of Engineering, 工博

** 神戸芸術工科大学 教授・工博 Yokohama National Univ., Dr. Eng. Prof., Kobe Design Univ., Dr. Eng.
} 
表一1 調査対象施設の概要

\begin{tabular}{|c|c|c|}
\hline & 木 - & K 木-ム \\
\hline 開設時期 & 1983 年 4 月 & 1960 年 8 月 \\
\hline 周辺状況 & $\begin{array}{l}\text { 都市近郊。周围に未開発の } \\
\text { 土地が多い新興住宅地 } \\
\text { 谪店等には遗い } \\
\text { 丘殿地で丘の上に立地 }\end{array}$ & $\begin{array}{l}\text { 既成市街地。一部工場や病 } \\
\text { 院などのる住宅地 } \\
\text { 周囲に生活利便施設は多い } \\
\text { 平地 }\end{array}$ \\
\hline 併設施設 & 特養・ケアセンター & 特養・賽護・ケアセンター \\
\hline 設備 & 設備専用（便所、洗面） & 設備共用（便所、洗面） \\
\hline その他 & キリスト教団体が母体 & 有料老人ホームとして設立 \\
\hline
\end{tabular}

\section{2. 研究の方法}

入所前後の生活状況を把握するために, 居住施設入居 者への調查をおこなった。これより，前半で，施設入所 にいたる生活拠点移動の要因とそのメカニズムを把握す る。さらに後半では, 入所前後の生活変化, 入所後のホー ム内生活などから入所による影響や施設生活への適応の 仕方を捉える。

\section{1 調查の対象}

本研究では, 主に老齢前期の施設入所の問題について 考察する。入所要因が身体的要因に集約される老路後期 の場合と異なり，老秢前期には様々な要因で施設入所す る可能性がある。また入所に当たり本人の自主性も加味 されることから, 在宅生活の条件の様々な側面が入所を めぐって理解しやすいことが考えられる。ここでの具体 的対象としては, 軽費老人ホーム入居者を採り上げた2)。 調査対象施設は立地条件, 設立時期の点などで性格の異 なる 2 施設を選び，その施設の全入所者とした ${ }^{3) 。}$

\section{2 調查の概要}

調査の内容は, 入所前の生活歴・諸事情と入所後の生 活状況であり，入所者による自記式調査を基本とし一部 聞き取り調查をおこない，各個人の詳細事項については 職員に対しての聞き取りやケース記録などにより客観的 な情報を補足した。

調査対象の 2 施設の概要を比較したものがく表一1> である。なお調查時期は 1984 年 10 月，回収状況は自記 式調查票に関しての有効数 A ホーム46/50（未記入 3 , 入院中 1 ) (92\%)，Kホーム49/49（100\%）である。

\section{3. 入所前の諸状況}

ここではまず，施設入所前の状況から入所をひきおこ す構造, 要因相互の関係について考察する。入所前生活 状況を捉え，入所に至るプロセスについて考察する。

3.1 入所者の概要

(1) 入居時年齢亡現在の年齢（表一2）

開設から間もないAホームは低年齢から高年齢までな

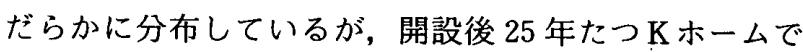
は，入所時すでに高路であった層のうちで死亡などの退 所者が多いため, 調査時点では 70 歳前後に入居した層
表一2 入居時年齢と現在の年齢

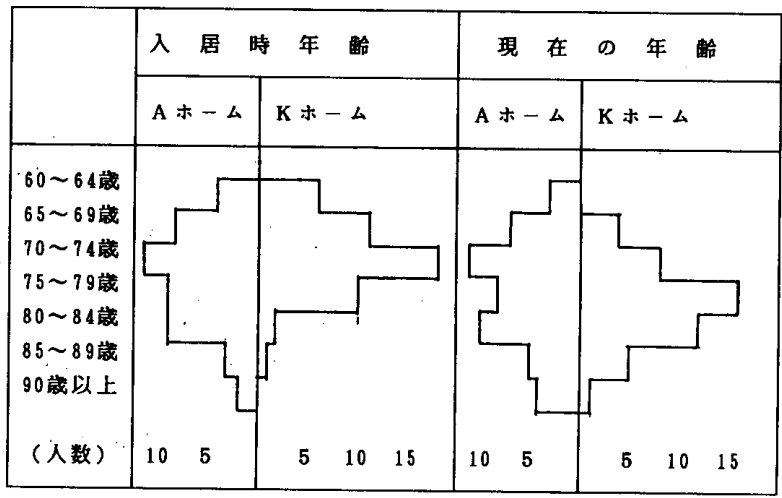

表一3 ホーム認知方法

\begin{tabular}{|c|c|c|c|}
\hline ホーム名 & A & K & 計 \\
\hline $\begin{array}{l}\text { 広報、パンフ } \\
\text { 友人の紹介 } \\
\text { 家族の紹介 } \\
\text { 相談員の紹介 } \\
\text { その他 } \\
\text { 不明 }\end{array}$ & $\begin{array}{r}9 \\
9 \\
8 \\
13 \\
3 \\
6 \\
\end{array}$ & $\begin{array}{r}8 \\
21 \\
5 \\
7 \\
8 \\
-\end{array}$ & \\
\hline 合計 & 46 & 49 & 9 \\
\hline
\end{tabular}

表一4 入所前住居形態

\begin{tabular}{|c|c|c|c|}
\hline ホーム名 & A & $\mathbf{K}$ & 計 \\
\hline $\begin{array}{l}\text { 戸建持ち家 } \\
\text { 户建借家 } \\
\text { 民間アパート } \\
\text { 公共住宅 } \\
\text { 分䛨集合住宅 } \\
\text { 給与住、宅、他 } \\
\text { 不明 }\end{array}$ & $\begin{array}{rl}1 & 4 \\
2 \\
11 \\
6 \\
5 \\
5 \\
3 \\
5\end{array}$ & $\begin{array}{rl}2 & 1 \\
& 3 \\
1 & 0 \\
5 \\
1 \\
1 \\
6 \\
3\end{array}$ & $\begin{array}{r}35 \\
5 \\
21 \\
11 \\
6 \\
9 \\
8\end{array}$ \\
\hline 合計 & 46 & 49 & 95 \\
\hline
\end{tabular}

単位 : 人

が多く残っている。

現在の年齢は，開設後期間が立っているKホームでは 軽費 $\mathrm{A}$ 型の全国平均)（76.5 歳）.よりも高く（78.6 歳）, 逆に開設後間もない A ホームは低く（75.8 歳）なって いる。

(2) ホーム認知方法 (表一3)

Aホームでは区役所, 相談所を介した入所が多いが, Kホームでは友人の紹介が多い。Kホームが古くから地 域に根付いたホームとしてよく知られた存在であること を示している。

(3) 入所前住居形態 (表一4)

一般の老人世帯と比べると持ち家率は低く民間アパー 卜などの割合が大きく，住宅困窮層対策としての軽費老 人ホームのひとつの意義がよくうかがえる。

\section{2 入所契機による分類の試み}

入所に至る経緯をみると，配偶者死亡による単身化な ど明確な生活変化（インパクト）を契機として入所した もの之, 入所理由は「老いたため」「将来の不安」など 入所にかかわる生活変化が特にないものと, 大きく 2 通 りの様相がみられた。そこで, 次の 2 つの型に分類を武 みた。

I・インパクト型

入所前 5 年以内に<表一 $5>$ に示すような大きな生活 条件の変化がありそれを契機に入所したもの II. ポテンシャル型

大きな生活変化はないが, 加齢による様々な能力の衰 
表一5 インバクトの内容

\begin{tabular}{|c|c|}
\hline 变化した & $\begin{array}{l}\text { 入所契機之関俰があると考えられるインパクト（生活条 } \\
\text { 件の麦化）の具体的内容 }\end{array}$ \\
\hline 家族条件 & 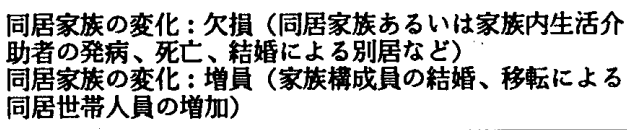 \\
\hline 経済条件 & 就労状況の变化（本人の退職、扶䆡者の倒産など） \\
\hline 居住条件 & 住居の变化（転居、取り嫂しによる立ち退き要求） \\
\hline 身体条件 & 体調の変化（発病、入院など） \\
\hline
\end{tabular}

表 6 入所契機の型別入所時の年跲，家族形態

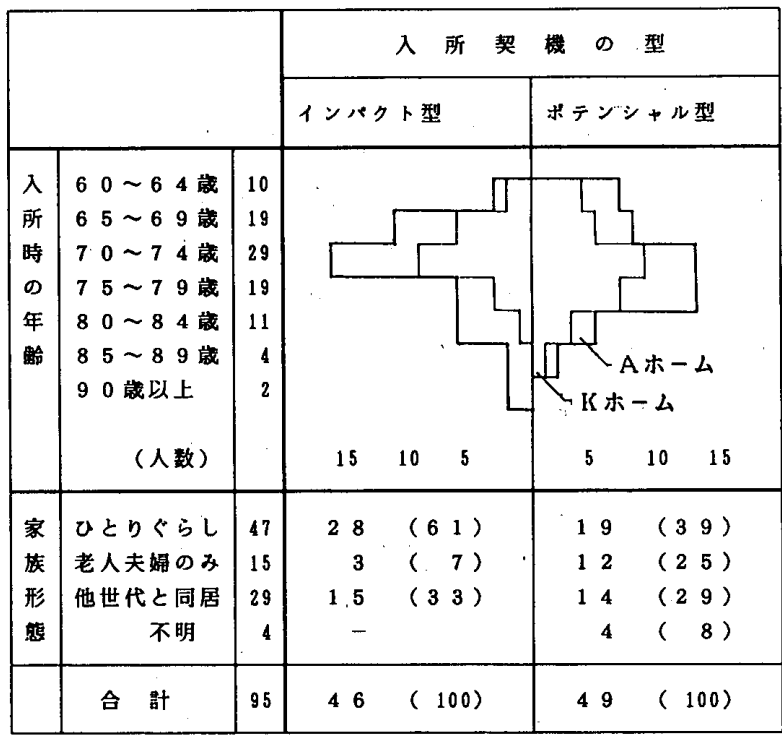

単位 : 人, () 内は $\%$

退, 周辺環境の悪化, 不安感の増大によって徐々に入所 志向が強まり入所に至ったもの

各型の特徵については次のような点が指摘できる。

(1) 入所時年齿 (表一6)

インパクト型は 70 歳中心にやや集中している。老齢 期における大きな生活変化は, 入所前 5 年以内，おおむ ね 60 歳後半に共通して起こりやすいものと思われる。

また，ポテンシャル型は，分散した分布をしているが， 65 歳以下の入所者が多く, 比較的若い時期に入所して いることが指摘できる。老路期に入るかなり前から入所 することを決心していて，年路が入所基準に適合する 60 歳に達するまで待っていたという事例も見られた。

(2) 入所時の家族 (表一6)

全体的にひとりぐらしが多いがインパクト型ではそれ が著しい。単身老人にとって何らかのインパクトが生じ ると在宅生活は脆く入所に直結しやすい状況がうかがえ る。

(3) . 入所前住所

インパクト型に地元，近隣地区のものが多く，この両 者の合計で 30 人である（そのほかの地区は 16 人）。一 方でポテンシャル型では，地元と近隣で合計 25 人に対
表一7 入所前の家族の状況

\begin{tabular}{|c|c|c|c|c|}
\hline & \multicolumn{2}{|c|}{ 入所前の家族の状況 } & \multirow[t]{2}{*}{ 合 計 } \\
\hline & & ひとりぐらし & 同居家族あり & \\
\hline $\begin{array}{l}10 \\
\text { ン内 } \\
\text { 傛 } \\
n \\
1\end{array}$ & $\begin{array}{l}\text { 家族の欠損 } \\
\text { 家族の增貝 } \\
\text { 就労の变 } \\
\text { 住居化 } \\
\text { 体調の変化 }\end{array}$ & $\begin{array}{r}15 \\
11 \\
8 \\
5\end{array}$ & $\begin{array}{l}9 \\
3 \\
2 \\
8 \\
1\end{array}$ & $\begin{array}{rr}24 \\
3 \\
13 \\
13 \\
16 \\
& 6\end{array}$ \\
\hline
\end{tabular}

数字はインパクト型入所者 46 人について入所前 5 年以内に起こった1 ンパクトの件数を示す

表一8 インパクト相互の関連がみられた例

\begin{tabular}{|c|c|c|c|}
\hline 先に起きた 後に起きた & 入所前の家族 & 状況 & \\
\hline インバクト インパクト & ひとりぐらし & 同居家族有り & 合 計 \\
\hline 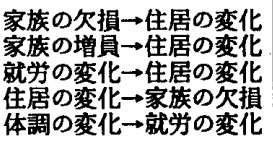 & $\begin{array}{l}2 \text { 例 } \\
0 \\
3 \\
9 \\
1\end{array}$ & $\begin{array}{l}2 \text { 例 } \\
1 \\
1 \\
1 \\
0\end{array}$ & $\begin{array}{l}4 \text { 例 } \\
1 \\
4 \\
10 \\
1\end{array}$ \\
\hline
\end{tabular}

表-9 入所前状況の点数化（入所前環境点）

\begin{tabular}{|c|c|}
\hline 生活状況 & 判断基準 \\
\hline 家族状況 & 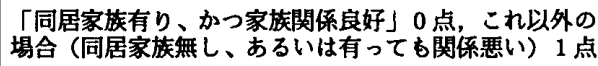 \\
\hline 住宅状況 & 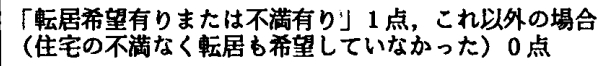 \\
\hline 释済状況 & 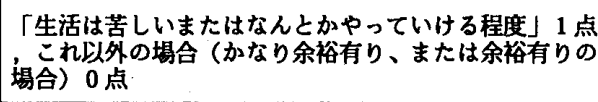 \\
\hline 身体状況 & $\begin{array}{l}\text { 「何らかの病気を持っている、または体調悪い」 } 1 \text { 点, } \\
\text { これ以外の場合（病気はなく、体調も悪くい）０点 }\end{array}$ \\
\hline 社会接触 & $\begin{array}{l}\text { 「何らかのクラプや団体に参加」0点, これ以外の場合 } \\
\text { (全く参加していなかった埸合) } 1 \text { 点 }\end{array}$ \\
\hline
\end{tabular}

し，そのほかは 24 人である。ポテンシャル型の方が地 域的に分散して入所者が分布している。

\section{3 入所インパクトの内容}

家族の状況としては，〈表一7〉より，入所前ひとり ぐらしであった者は家族欠損の結果の単身化が最も多く 見られるが，同居家族の居た場合でも日常身の回りの世 話をしてくれる者（配偶者, 娘なざ）の欠損というイン パクトが重要となっている。逆に，家族増員により住宅 が狭くなり老人がその家を出るという入所の仕方もあ る。<表一8>のように住宅のインパクトは同時に起き た場合を含めて複合的に生じる例がよく見られ，住居の 状況変化は入所行為に関係が樑い。

\section{4 入所前環境による分類}

入所前環境を大きく $5 つ$ つ生活条件からなるものと想 定し，それぞれの困難状況に対し〈表一9>のごとく点 を与え，総点を入所前在宅状況の困難度の目安とした ${ }^{55}$ 。 点数分布はく表一10>に示したが，このうち平均的なも のよりも困難度の值の低い（2点以下）層を自ら入所決 定する余地のある層として「自発的入所型」，そのほか 一般の多くを「受動的入所型」と仮称する。

先に分類した入所契機による型との対応を（表一11） 
表一10 入所前環境点分布

\begin{tabular}{|r|r|r|r|r|r|r|}
\hline 点数 & 1 & 2 & 3 & 4 & 5 & 計 \\
\hline 人数 & 8 & 18 & 45 & 17 & 7 & 95 \\
\cline { 2 - 6 } & $\begin{array}{c}26 \\
\text { 自発的人所型 }\end{array}$ & \multicolumn{3}{|c|}{69} \\
受動的入所型 & 95 & 単位 : 人 \\
\hline
\end{tabular}

表一11．入所契機と入所前環境

\begin{tabular}{|l|c|c|}
\hline & 自発的入所型 & 受動的入所型 \\
\hline インバクト型 & 10 & 36 \\
\hline ポテンシャル型 & 16 & 33 \\
\hline
\end{tabular}

単位: 人

より見ると，自発的入所型では，ポテンシャル型がやや 多い。このタイプは長い間入所意志を持ち続けていた人 たちで，自主的入所意識の特に高い層であると言える。 また受動的入所型では，インパクト型も多く含まれてい ることからインパクトが複合して困難度が増したため受 動的に入所をした層がいることが想像できる。

\section{4. 入所者の施設内生活}

次に, 入所後の生活行動つまり生活扰点移動後の適応 が入所前の状況や周辺地域とのかかわりでどのような差 を生じるのか, についてとくに社会活動性の面から考察 する。ここでは, 実際の施設内での生活をアンケート調 查などから把握し, 活動のパターンをよらえる。

表一12 健康状態

\begin{tabular}{|c|c|c|c|c|c|}
\hline & Aホーム & Kホーム & 合 計 \\
\hline \multicolumn{2}{|c|}{$\begin{array}{l}\text { 入所前の } \\
\text { 硉康状態 }\end{array}$} & 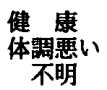 & $\begin{array}{l}17 \\
27 \\
22 \\
7\end{array}\left(\begin{array}{ll}4 & 4\end{array}\right)$ & $\left.\begin{array}{rrrr}3 & 2 & \left(\begin{array}{ll}7 & 0\end{array}\right) \\
1 & 4 & (3 & 0\end{array}\right)$ & 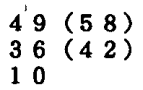 \\
\hline \multicolumn{2}{|c|}{$\begin{array}{l}\text { 現在の } \\
\text { 侓康状態 }\end{array}$} & $\begin{array}{c}\text { 徒康 } \\
\text { 体調悪い } \\
\text { 不明 }\end{array}$ & 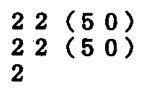 & $\begin{aligned} 21 & \left(\begin{array}{ll}4 & 3\end{array}\right) \\
8 & \left(\begin{array}{ll}5 & 7\end{array}\right)\end{aligned}$ & 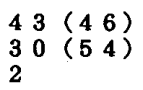 \\
\hline $\begin{array}{l}\text { 受 } \\
\text { 福 }\end{array}$ & \multicolumn{2}{|c|}{ 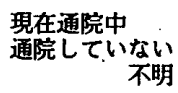 } & $\begin{array}{l}17\left(\begin{array}{ll}1 & 4\end{array}\right) \\
22 \\
7\end{array}$ & 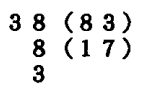 & 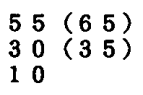 \\
\hline \multicolumn{3}{|r|}{ 合計 } & 46 & 49 & 95 \\
\hline
\end{tabular}

単位 : 人（）内は不明を除く合計に対する\%

表一13 面会・外出状況

\begin{tabular}{|c|c|c|c|c|}
\hline & & Aホーム & $\mathrm{K} ホ ー ム$ & 合 計 \\
\hline $\begin{array}{l}\text { 面 } \\
\text { 䔛 } \\
\text { ( }\end{array}$ & $\begin{array}{l}\text { 全くない } \\
\text { 年に数回 } \\
\text { 月 } 1 \text { 2回 } \\
\text { 遇1 回程度 } \\
\text { それ不明 } \\
\text { 不明 }\end{array}$ & 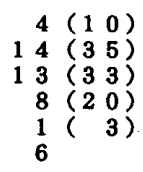 & 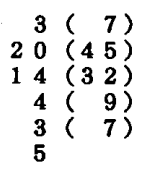 & 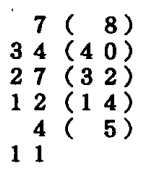 \\
\hline $\begin{array}{l}\text { 外 } \\
\text { 蘋 }\end{array}$ & $\begin{array}{l}\text { 毎 } \\
\text { 過 } 3 \text { 茴以上 } \\
\text { 週 } 1 \text { 回程度 } \\
\text { 月1 } 2 \text { 回 } \\
\text { そ九以下 } \\
\text { 不明 }\end{array}$ & 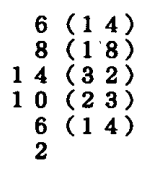 & 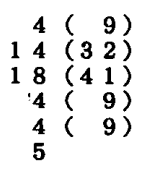 & 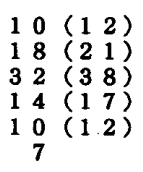 \\
\hline & 合 & 46 & 49 & 95 \\
\hline
\end{tabular}

単位 : 人（）内は不明を除く合計に対する\%

\section{1 入所者の施設内生活の概要}

施設内外に通じて活動性に大きく関与するものが健康 状態である。これをく表一12>より見ると古い施設であ るKホームにおいては入所前健康であった人が多いが全 体の高齢化により現在の状況に変化している。

またく表一13〉より外部社会との接触方法の一つとし て, 面会についてみてみる亡, 月 1,2 回が平均的な値 である。施設別にみてみると, Kホームの方が長期在所 者が多いため比較的面会は少ない。

次に外出について見てみると, 週 1 回が平均的だが, 立地条件の良い $\mathrm{K}$ ホームの方が高齢者入居者が多いにも かかわらず，やや多い方に偏っている。また，外出頻度 を入所前と比較してもらった回答によると「減った」72 \%,「変化なし」 $17 \%$,「増えた」 $11 \%$ であり, 大半が減っ ている。「増えた」の中には病院への通院も含まれるこ と（現在の主な外出先が病院のみの者 24 名 /88名）を 考慮すると，実質的には総じて入所により外出行為は縮 小しているとみなすことができよう。

\section{2 施設外団体への参加状況}

生活拠点の移動はそれ以前に住んでいた地域社会との 断絶を意味すると思われる。ここでは，地域社会に限ら ないが，交友の場が移動後も維持されているかどうか, について施設外団体への参加状況とその入所前後の変化 を調べた（表一14）。

入所前に参加していた団体で入所後参加できなくなっ たもののうち, 老人クラブ, 町内会などは地域社会内で 活動することの多いものである。趣味の会については, 新たに参加し始めるなどの変化も多く見られ，このよう な場がホームに用意されていることは重要である。老人

表一14 施設外団体への参加 · 入所前後の変化

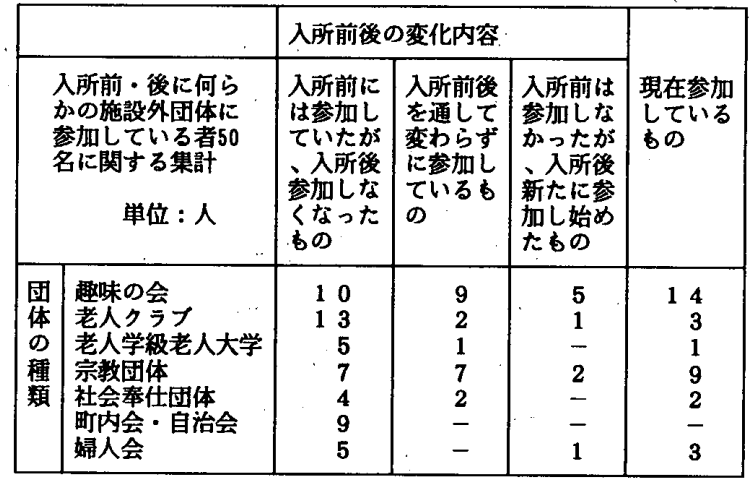

表一15 施設外団体への参加・入所前住所との関係

\begin{tabular}{|c|c|c|c|c|}
\hline 变化 & 入所前参加状況 : 入所後参加状況 & 同一市 & そ.の他 & 合計 \\
\hline 喪失 & 1 つ以上に参加 : 全く参加しない & 3 & 20 & 23 \\
\hline 維持 & 1 つ以上に牵加：1 つ以上に参加 & 7 & 16 & 23 \\
\hline 獲得 & 全く参加しない： 1 つ以上に参加 & 1 & 3 & 4 \\
\hline & 調查対象者全数 & 25 & 70 & 95 \\
\hline
\end{tabular}


の参加する団体はもともと，ここで見る限り地域に密着 したものが多いため, 施設入所によりそれら団体と断絶 することが多いと言える。また，〈表一15>より，例数 が少なく断定はできないが，同一市内から入所してきた 場合の方が「喪失」する割合が小さいことがうかがえる。 4.3 入所後生活の型分類の試み

<図一1>のように, 生活拠点移動後のホームにおけ る集団生活にいかにとけこんでいるかという点で，社会 的適応性としての活動性に着目した入所生活の型分類を 試みた。すなわち，まず社会的交流のある活発型とそう ではない不活発型にわけ, 不活発型のうち自己活動とし て創造的な趣味を持たない沈澱型と趣味を持つ楽隠居型 とに分けた。次に活発型の中を交流の相手により，施設 内部の人との交流を主にしている内向き型，外部との交 流が主の外向き型，両者ともに活発な内外向き型の 3 つ のタイプに分けた。

以下, 各タイプの特徵を入所前の状況との関係を考察 しつつ述べる。

\section{(1) 不活発沈澱型}

外出がほとんざなく, 知人, 親友数も不明またはなし, 部屋の交流もなく趣味もない人がこのタイプである。体 調が悪いための沈澱と，施設内での不和に起因する沈搌 とが考えられる。

このタイプには体調悪く活発な生活がおくれなくなっ た者が多いと思われる。また平均年齢が高いことから， 高齢によって不活発になったと推察される。〈表一16> より，例数も少ないが，とりわけ長期間入居している人 に多いとは言えず，入所初期から施設不適応傾向のある 者が存在すると思われる。徐々に増えることが予想され る層で，施設の活性化にとっては好ましくないので，施 設不適応をおこしやすい人にとっては在宅サービスが十 分に供給されて地域生活を行えるような制度的配虑が望

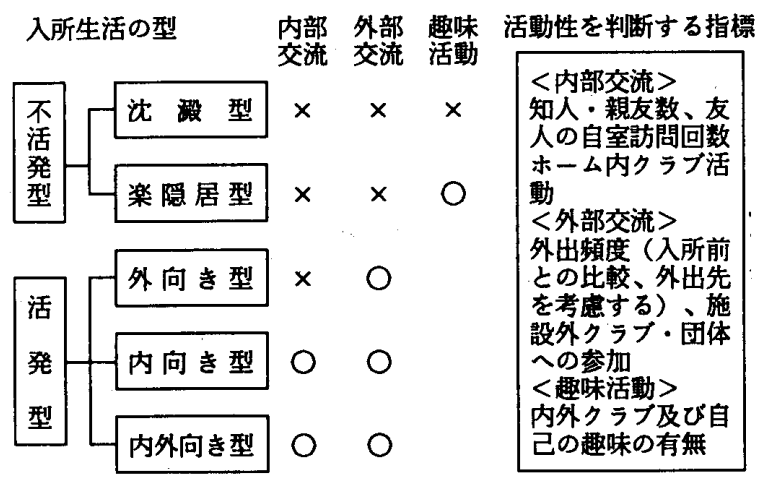

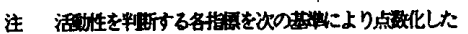

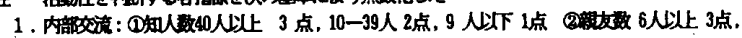

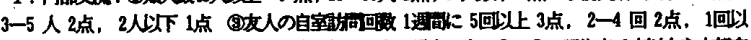

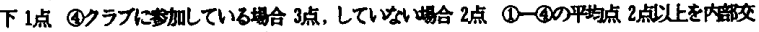
澈とする

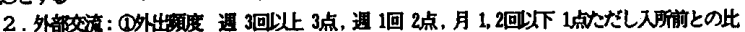

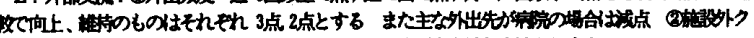

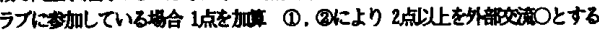

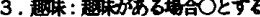

図一1 入所生活の型分類
表一16 入所生活の型別諸属性

\begin{tabular}{|c|c|c|c|c|c|c|c|}
\hline \multirow{3}{*}{\multicolumn{2}{|c|}{. }} & \multicolumn{5}{|c|}{ 入 所 生 活 の 型 分 類 } & \multirow[b]{3}{*}{ 合 計 } \\
\hline & & \multicolumn{2}{|c|}{ 不 活 発 型 } & \multicolumn{2}{|l|}{ 活 } & 型 & \\
\hline & & 沈殿 & $\begin{array}{r}\text { 亲隠居 } \\
\text { 型 }\end{array}$ & $\begin{array}{c}\text { 外向き } \\
\text { 型 }\end{array}$ & $\begin{array}{r}\text { 内向き } \\
\text { 型 }\end{array}$ & $\begin{array}{l}\text { 内外 } \\
\text { 向き型 }\end{array}$ & \\
\hline 性 & 男 & $\begin{array}{l}2 \\
6\end{array}$ & $\begin{array}{r}6 \\
19\end{array}$ & $\begin{array}{r}3 \\
13\end{array}$ & 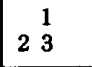 & $\begin{array}{r}8 \\
13\end{array}$ & $\begin{array}{ll}2 & 0 \\
7 & 4\end{array}$ \\
\hline $\begin{array}{l}\text { 前 } \\
\text { 住 }\end{array}$ & $\begin{array}{l}\text { 同一市内 } \\
\text { 近粠内 } \\
\text { その他 }\end{array}$ & $\begin{array}{l}4 \\
1 \\
3\end{array}$ & $\begin{array}{r}5 \\
7 \\
13\end{array}$ & $\begin{array}{l}6 \\
4 \\
6\end{array}$ & $\begin{array}{ll} & 2 \\
1 & 0 \\
12 & 2\end{array}$ & $\begin{array}{l}8 \\
7 \\
6\end{array}$ & $\begin{array}{ll}2 & 4 \\
2 & 9 \\
4 & 1\end{array}$ \\
\hline & 匀年睮 & 81.8 瓷 & 79.6歳 & 75. 7惄 & 77. 6歳 & 73. 3墄 & 77.2歳 \\
\hline & $\begin{array}{l}-\Delta \\
i=\Delta\end{array}$ & $\begin{array}{l}2 \\
6\end{array}$ & $\begin{array}{ll}1 & 1 \\
1 & 4\end{array}$ & $\begin{array}{r}6 \\
10\end{array}$ & $\begin{array}{ll}1 & 4 \\
1 & 0\end{array}$ & $\begin{array}{r}12 \\
\quad 9\end{array}$ & $\begin{array}{l}45 \\
49\end{array}$ \\
\hline 合 & 計 & 8 & 25 & 16 & 24 & 21 & 94 \\
\hline
\end{tabular}

表一17 Kホームにおける入所生活の型と入所期間

\begin{tabular}{|c|c|c|c|c|}
\hline \multirow[b]{2}{*}{ 入所生活の型 } & \multicolumn{2}{|c|}{ 可 期 } & \multicolumn{2}{|l|}{ 間 } \\
\hline & 1 年以内 & 1 5年 & $5 \sim 10$ 年 & 10 年以上 \\
\hline 不活発・沈殿型 & & 00 & 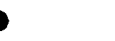 & 10 \\
\hline 不活発 - 楽隠居型 & & 0 & & \\
\hline 活発・内向き型 & & 000 & & \\
\hline 活発 • 外向き型 & & & & 0 \\
\hline 活発 - 内外向き型 & & 0 & 90 & \\
\hline
\end{tabular}

ましい。

(2) 不活発楽隠居型

外出はほとんだなく, 知人, 親友も少なく, 部屋の交 流も比較的少ない夕イプ。趣味を持っているが, その内 容は活発型の入居者に比べて，読書，編み物など個人的 な趣味が主である。

このタイプの性別の内訳は, 男 6 人, 女 19 人であり, 比率では全体と変わらない。しかし，男性であるために 施設内のコミュニティに溶けこめず，不適応状態になっ ている場合もあるようである。特に夫婦入所の場合の男 性は会話の相手は配偶者だけという例も生じやすい。こ の場合は，話相手としてはすでに妻が傍らにいるので， 自ら進んで交友関係を広げようとはしない。このため不 活発になっているものと思われる。女性は，女性同士で 固まる傾向がみられ，少数派の男性はごうしても施設生 活集団から遊離しやすい。施設側で企画するクラブ活動 をみても，これは男性向き，これは女性向き，と分けら れて用意されているのが現状だが，男女混合のコミュニ ティをどう育てていくかが問題となろう。

〈表一18>より, 入所要因についてみると, 全体と比 較していえることは，家族との不和が少なく，負担を避 ける，とか不安など，精神的な原因によるものが多いこ とで，一種の予防的入所が多いといえよう。特に，老夫 婦入所が多いのが特徵で, 夫婦内でコミュニティが完結 
表一18 楽隠居型の入所理由

\begin{tabular}{|c|c|c|}
\hline & 楽隐居型 & 全 体 \\
\hline $\begin{array}{l}\text { 一人の不安 } \\
\text { 家族亡の不和 } \\
\text { 負担さけたい } \\
\text { 老夫婦の不安 } \\
\text { その他 }\end{array}$ & $\begin{array}{l}14 \text { 人 }(54 \%) \\
1 \text { ( }(4 \%) \\
5 \hat{人}(19 \%) \\
4 \hat{人}(15 \%) \\
2 人(8 \%)\end{array}$ & $\begin{array}{r}49 \% \\
14 \% \\
11 \% \\
10 \% \\
6 \%\end{array}$ \\
\hline
\end{tabular}

表一19 タイプ別入所前住所

\begin{tabular}{|c|c|c|c|c|}
\hline & 内向き型 & 内外向き型 & 外向き型 & 全 \\
\hline $\begin{array}{l}\text { 地元市内 } \\
\text { 近隣市内 } \\
\text { その他 }\end{array}$ & $\begin{array}{l}2 \hat{\text { 人 }}(8 \%) \\
10 \hat{\text { ( }}(42 \%) \\
12 \hat{\text { 人. }}(50 \%)\end{array}$ & $\begin{array}{l}8 \text { 人 }(24 \%) \\
7 \text { 人 }(33 \%) \\
6 \text { 人 }(29 \%)\end{array}$ & $\begin{array}{l}6 \hat{\text { 人 (38\%) }} \\
4 \text { 人 (25\%) } \\
6 \text { 人 (38\%) }\end{array}$ & $\begin{array}{ll}24 & (26 \%) \\
29 & (31 \%) \\
40 & (43 \%)\end{array}$ \\
\hline
\end{tabular}

している場合が 1 組と，夫婦入所した場合の夫が 2 例 あった。つまり夫婦入所した場合，特に夫の方は「妻」 という話し相手がいる以上あえてほかの人たちとはつ きあう必要がないわけで，施設内コミュニティに消極的 になっている。

空間的には居室に適度な接客の場を確保できれば, 配 偶者の友達が訪問するなどをきっかけにして交流の輪が 広がることもあり得る。

(3) 外向き型

外出頻度が高く, 施設外クラブにも参加するなど地域 的な活発性が高いにもかかわらず施設内では知人数, 親 友数が少なく, 交流が比較的少ない人がこの夕イプであ る。

〈表一19>より，前住所について見ると，全体とくら べて，地元市内が若干多い。この中には，入所前からの なじみの土地ということで入所前コミュニティが維持さ れている場合があると思われる。一方，まったくなじみ のない土地にあるホームに入所した場合，そこでの地域 社会参加は高齢者にとってかなり勇気のいることであ りおっくうになりがちとなろう。

不活発型に比べかなり若く，入所期間も短いところに 集中しており，日が浅いために施設になじめない者も居 ると思われる。この中には入所前のなじみのコミュニ ティが維持されている場合があると思われる。またこの タイプは在所が長くなるにつれ老化が進み身体状況の低 下から外に出にくくなり，そのまま内との交流がない場 合には不活発型になることが予想される。建築計画的に も，居室か外部かという二者択一的な生活ではなく，内 部の隣人との適度な交流が生まれるように，生活を活性 化するなんらかの仕掛けが必要となる。

(4) 内向き型

外出は少なく，その目的も病院なぼ必要にせまられて の場合が多い。地域社会には参加していないが，施設内 では知人, 親友数も多く, 部屋の訪問も盛んなタイプで ある。
入所前住所をみると,〈表一19〉でも明らかなように， 地元市内出身が圧倒的に少ない。つまり入所前コミュニ ティの維持が困難なものがこのタイプには多いことがわ かる。

またAホームは最長 1.5 年の在所期間だが, $\cdot \mathrm{K}$ ホーム より内向き型が多い。Kホームでは長期在所者による交 友関係がすでに固定化していること，あるいは沈澱型の 多いことによる全体の雾囲気の沈滞化によって, 新しい 入所者が施設内の交友関係に入り込みにくいなどの理由 が考えられる。

(5) 内外向き型 (男 8 例，女 13 例)

外出が多く, 施設内でも知人, 親友が多く, 地域社会 的にみても，施設内でみても活発なタイプ。最も活動性 に富み，かつ施設生活に適合したタイプである。

〈表一19>より, 前住所について全体と比較すると, 地元出身が多く遠隔の人が少ない点が特徽である。入所 前居住地との接近が, 入所前コミュニティと現在の生活 の両立を可能にしているものと思われる。また，〈表一 18>より，在所期間について見ると長期入居者がいない ことがわかる。つまり現在内外向き型であっても，いず れ老化により外部交流がしにくくなり内向き型に移行し ていくなどの将来が予想される。

\section{5. 入所前と入所後生活との関係}

これまでみてきた入所生活は，このように，入所前の 居住地, 年齢, 心身条件, 入所時の家族状況など, 入所 前の事情が影響していることが指摘できよう。移動によ る環境変化だけではなく, 入所前の生活や環境条件も, 入所後の生活のしかたと少なからずかかわりがあると思 われる。

'最後に, 入所前のプロセスとの関係について, 前半で 述べた入所前状況の型と, 後半で述べた入所生活の型と の対応関係を見たものがく表一20>である。これより， 例数が少なく断定は難しいが, やや傾向が認められると 思われるものは次の 2 つの関係である。

\section{表一20 入所前状況の型と入所生活の型との対応}

\begin{tabular}{|c|c|c|c|c|c|c|}
\hline \multirow{3}{*}{ 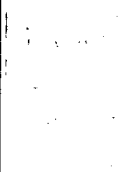 } & \multicolumn{6}{|c|}{ 入 所 生 活 $の$ 型 分 類 } \\
\hline & 不 活 & 発 型 & 活 & 発 & 型 & \\
\hline & 沈殿 & $\begin{array}{r}\text { 楽隠居 } \\
\text { 型 }\end{array}$ & 外向き & 内向き & $\begin{array}{l}\text { 内外 } \\
\text { 向き型 }\end{array}$ & 合 計 \\
\hline $\begin{array}{l}\text { 受動的 } \\
\text { 狮 }{ }^{*} \text { 外型 }\end{array}$ & 2 & 8 & 10 & 9 & 6 & 35 \\
\hline 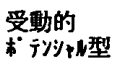 & 4 & 8 & 3 & 9 & 9 & 33 \\
\hline 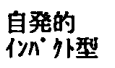 & 0 & 3 & i & 4 & 2 & 10 \\
\hline $\begin{array}{l}\text { 自発的 } \\
\text { 末 } \\
\text { “型 }\end{array}$ & 2 & 6 & 2 & 2 & 4 & 16 \\
\hline 合竐 & 8 & 25 & 16 & 24 & 21 & 94 \\
\hline
\end{tabular}


(1) 受動的インパクト型 $\rightarrow$ 外向き型

入所に対する心構えが不十分な時期にやむなく入所し たタイプで，この場合は施設内でうまく適応しにくく， 社会的交流はそれまでのコミュニティに依存し，外部の 友人関係などを生活の中心におくことになる

(2) 自発的ポテンシャル型 $\rightarrow$ 楽嗳居型

おそらく施設の日常サービスを求めての本人の自発的 意志による入所で，必ずしも共同生活を欲してはいない ものと思われ，したがって施設生活にうまくなじめない。 施設に求めるものはサービス機能だけであり, 必然的に それに付随する共同生活の強制に対しては固くカラを閉 ざすこととなる。

これらはいずれも施設適応しにくい沈溜層予備群であ ると言える。これらの層に対しては入所に至らずに済む 在宅サービスの整備がのぞましい。とくにインパクト型 の入所に対しては，入所の危機がおこりやすい時期に生 活条件の安定を確保することが重要であると言えよう。

また，施設内の交流を促進し，内向き型への転換をし やすい施設計画が必要となる。たとえば，施設の居室は 寝るだけのためにあり, 部屋の外では大集団の共同生活 を強いられるようなこれまでのあり方を見直す必要があ る。両者の中間的な生活として, 入所者同士で小規模の 交流が自然にできるような共用空間の配慮が必要であ り, 居室に関しても, 接客のできるスペースの確保など が計画上重要な視点となる。

\section{6. まとめ}

はじめに，入所に至るプロセスに関しては，以下のよ うな点が明らかになった。

(1) 入所理由には，様々な在宅生活条件の欠如加らくる 外的要因と, 老化の進展に対する施設の安心感なざ心理 的要因があり，外的要因が勝って半ばやむを得ず入所に 至る受動的入所型と，外的要因がほとんどなく本人が自 ら望んで入所していると思われる自主的入所型とが存在 することがわかった。

(2) 入所に至る経緯をみると, 配隅者死亡による単身化 など明確な生活変化 (インパクト)を契機として入所し たものと, 入所にかかわる生活変化が特にないものと, 大きく 2 通りの様相がみられた。そこで, 前者の「イン パクト型」と後者の「ポテンシャル型」の 2 つの型に分 類できる。

(3) 入所契機としてのインパクト要因には家族, 経済, 身体，居住などさまざまであり，なかでも特に住宅の要 因はほかの要因と連鎖的に生じていることが多い。

(4) インパクト型の入所時期は 70 歳中心にやや集中し ている。一方，ポテンシャル型の入所時期は，分散した 分布をしているが，比較的若い時期に入所している。

次に，移動による影響としては，以下のような点が明
らかになった。

(1) 外出行為については, 大半が減っている。入所前と 比べて外出が増えたものの中には病院への通院も含まれ ることを考虑すると, 総して入所により外出行為は縮小 しているとみなすことができる。

(2) 老人の参加する団体は, 地域に密着したものが多い ため，施設入所によりそれらの団体と断絶することが多 い。また，前住地が遠いものよりも，同一市内から入所 してきた場合の方が参加団体を「喪失」する割合が小さ い。

(3) 入所後の生活について活動性からタイプ分けをする と，5つに分けられ，そのうち社会生活が活発な中にも 施設の外部との接触が主な「外向き型」と，施設内だけ で交際がほぼ完結している「内向き型」とがあり，入所 初期の頃は「外向き型」がやや多い。

(4) 入所前状況の型と入所生活の型との対応関係をみた 場合，入所時インパクトが大きな引金になり十分に考慮 できず入所してきた人は，入所後に施設不適応を起こす 可能性が高いこと,つまり他律的要因による入所は適応 困難を引起こすことが予測される。

(5) さらに入所後, 自主的に入所したポテンシャル型は 楽隠居生活になりやすく, また他律的に入所したインパ クト型の交際はホームの外部が主になりやすいなどの対 応が見られた。これらはいずれも, 居住期間が経るにつ れて活動性が低下した場合, 閉じ込もりがちになりやす いことが予想される。

以上より, 高齡者の入所後の生活はとくに社会活動性 の点からみると,概して生活を縮小する方向に働くこと, 施設内の生活に適応しにくい層が存在することなどか ら, 在宅生活を維持することの重要性が認識された。

移動の起こった場合の適応を支えるための環境上の整 備課題は, 社会生活を切り離さない配慮が重要である。 このため, 地域社会を離れずにすむケアサービスのネッ トワーク整備が重要となる一方で, 施設計画としては, 全体共同生活か個人生活かの二者択一を強いるのではな く，接客空間などを確保しその二者の中間の隣人生活が 形成されるような空間的配慮が必要である。このために は多様な居住スタイル・生活様式を画一的にさせない共 同生活のあり方が施設管理上, 求められる。

なお，今回の調查では入所した者のみを対象としたこ とから, 入所前の状況の詳細な把握には調査上の限界が ある。また, 入居してからの個人の経時的な変化を捉え るために, 継続調查を行っており, 入居後長期間在所し た場合の生活変化を考察することが, 今後の課題として 考えられる。

\section{謝 辞}

最後に本報告の調査は, 調查対象となった入所者の 方々および施設の職員の方々に多大なご協力をいただい 
た。また調査分析には藤田保夫氏（(株) 竹中工務店） の尽力によるところが大きい。ここに深く感謝の意を表 します。

注

1）とくに移動を前提とした居住体系の徹底しているアメリ 力においては，文1，2 などにまとめられているように， 環境の変化が健康や心理尺度，死亡率などに与える影響 についての研究は多くおこなわれている。一般的に，移 動することは高㱓者にとってネガティブに作用するとさ れる。しかし自発的入所と強制的入所の場合の違いや, 学歴や様々な主体条件の要因が複雑にかかわっており， また条件によっては健康度や死亡率には転居群の方が良 好とする全く逆の結論も得られており（文 3 ），一概には 言えない。

2）本研究で軽費老人ホームを研究対象として選んだ理由は 以下のとおりである。

(1) 軽費老人ホームは，現行の制度下で住宅対策と福祉 施策の両面を持つものであり今後の老人居住のありかた を考える上でその機能が固定的でないだけに将来の方途 を探る意味で興味樑い。

(2) したがって，施設機能として入所者が求めるものが 多様であり，養護老人ホームあるいは有料老人ホームの ように経済的に入所対象者層が固定されていない。

(3) 措置施設ではなく契約施設であることから，ほかの 老人ホームと比べて本人の意志による施設選択の可能性 が高い。様々な環境要因 (客観的条件) と本人の意志 (主 観的条件）とが複合し関係し合って入所行動を生み出し ては，有料老人ホームとして位置づけられており，現在
高龄者向け住宅として数多く建設されつつある有料老人 ホームの今後の方向を探るうえでも参考となる。

3）施設の選定に当たっては，次の 2 点を考虑した。

(1) 立地条件：外部との接触, 地域生活は施設の周辺状 況に左右されると思われるので，地域との密着度の違い をみるために，居住地にとけ込んだ施設と，やや交通の 便が悪く市街地から離れた施設とを選んだ。

(2) 設立时期 : 老人ホームが年数を経たときの変化や入 所期間の長期化によるコミュニティ醽成など入所生活へ の影響を見るため,古くに開設され入居者構成が定常化 している施設と，最近新規に開設された施設とを選んだ。

4）軽費老人ホーム入所者全国調查（社会福祉協議会 1979） のデータによる。

5）原則として，各生活状況の悪い場合を 1 点と得点してい る。したがって，生活を困難にしている状況が大きいほ ビ合計点は高くなる。

\section{参考文献}

1) Schulz, R., \& Brenner, G. : Relocation of the aged : A review and theoretical analysis. Journal of Gerontology, pp. 323 -333, p. 32, 1977

2) Kasl, S. : Physical and mental health effects of involuntary relocation and institutionalization : a review, American Journal of Public Health, p. 62, pp. 379 384, 1972.3

3) Carp, F. M. : Impact of improved living environment on health and life expectancy, Gerontologist, p. 17, pp. 242 $\sim 249,1977$

(1992 年 5 月 10 日原稿受理, 1992 年 9 月 8 日採用決定) 